\title{
Cardiotrophin-Like Cytokine Factor 1
}

National Cancer Institute

\section{Source}

National Cancer Institute. Cardiotrophin-Like Cytokine Factor 1. NCI Thesaurus. Code C25984.

Cardiotrophin-like cytokine factor $1(225 \mathrm{aa}, \sim 25 \mathrm{kDa}$ ) is encoded by the human CLCF1 gene. This protein is involved in cytokine signaling. 